\title{
KETAHANAN HIDUP DAN PERTUMBUHAN NYAMUK Aedes spp PADA BERBAGAI JENIS AIR PERINDUKAN
}

\author{
${ }^{1}$ Aprianto Jacob \\ ${ }^{2}$ Victor D. Pijoh \\ ${ }^{2}$ G. J. P. Wahongan \\ ${ }^{1}$ Kandidat Skripsi Fakultas Kedokteran Universitas Sam Ratulangi Manado \\ ${ }^{2}$ Bagian Parasitologi Universitas Sam Ratulangi Manado \\ Email: apriantojacob@gmail.com
}

\begin{abstract}
In Indonesia there are two vectors are known, the main vector Aedes aegypti and Aedes albopictus as a potential vector, Aedes spp mosquito breeding varies but generally prefer clear water reservoirs. Eggs Aedes spp mosquitoes can hatch in the sewage, although not known survival and growth of larvae into pupae and adult mosquitoes. Objective: To determine the survival and growth of Aedes spp in various types of water breeding. Methods: Four types of breeding water taken directly from the settlement, and immediately used. Eggs Aedes spp laboratory strains incubated in water media. Larvae reared until the age of 4 days. A sample of 25 healthy larvae included six types of breeding water. The number of surviving larvae, pupae and adult mosquitoes be observed and counted every day for 15 days. Data security and growth of larvae processed manually in the form of percentages and graphs. Results: Aedes spp shown to survive in water dug wells (SGL), sewage water (sewer), as well as tap water. The presence of mosquitoes living in the sewer water can last up to 15 days with the same amount of mosquitoes from the first day until the last day. This phenomenon is different in the SGL and PAM water where mosquitoes can survive until day 15, although with a small percentage. Aedes spp proved unable to survive in wastewater soap.
\end{abstract}

Conclusion: Water drains were left in place and clear become breeding places for Aedes spp good to note that its presence in the cleaning mosquito breeding.

Keywords: The larvae of Aedes spp, life, death, pupa, adult mosquitoes, breeding water.

\begin{abstract}
Abstrak: Di Indonesia dikenal ada dua vektor, vektor utama nyamuk Aedes aegypti dan Aedes albopictus sebagaivektor potensial, perindukan nyamuk Aedes spp sangat bervariasi tetapi umumnya lebih menyukai tempat penampungan air jernih. Telur Aedes sppdapat menetas pada air comberan,meskipun belum diketahui ketahanan hidup dan pertumbuhan larva menjadi pupa dan nyamuk dewasa. Tujuan: mengetahui ketahanan hidup dan pertumbuhan nyamuk Aedes spp pada berbagai jenis air perindukan. Metode: Empat jenis air perindukan diambil secara langsung dari pemukiman penduduk dan langsung digunakan. Telur Aedes spp strain laboratorium ditetaskan pada media air bersih. Larva dipelihara hingga berumur 4 hari. Sampel sebanyak 25 ekor larva sehat dimasukkan ke enam jenis air perindukan. Jumlah larva yang bertahan hidup, menjadi pupa dan nyamuk dewasa diamati dan dihitung setiap hari selama 15 hari. Data ketahanan dan pertumbuhan larva diolah secara manual dalam bentuk persentase dan grafik. Hasil: Nyamuk Aedes spp terbukti dapat bertahan hidup pada air sumur gali (SGL), air comberan (got), serta air PAM. Keberadaan nyamuk hidup pada air got mampu bertahan sampai 15 hari dengan jumlah nyamuk yang sama dari hari pertama sampai hari terakhir. Fenomena ini berbeda pada air SGL dan PAM dimana nyamuk mampu bertahan sampai hari ke-15 meskipun dengan persentase kecil. Nyamuk Aedes spp terbukti tidak dapat bertahan hidup pada air limbah sabun. Simpulan: Air got yang didiamkan dan jernih menjadi tempat perindukan yang baik bagi Aedes spp sehingga keberadaannya perlu diperhatikan dalam pembersihan sarang nyamuk.
\end{abstract}

Kata kunci: Larva Aedes spp, hidup, mati, pupa, nyamuk dewasa, air perindukan. 
Aedes spp merupakan vektor Demam Dengue (DD) dan Demam Berdarah Dengue (DBD), Aedes sppsudah tersebar di seluruh negara tropis, kira-kira terjadi 50 juta infeksi demam berdarah di lebih dari 100 negara setiap tahun. ${ }^{1}$ Di Indonesia dikenal ada dua vektor, vektor utama nyamuk Aedes aegypti dan Aedes albopictus sebagaivektor potensial, keduanya tersebar di seluruh pelosok tanah air, kecuali yang ketinggiannya lebih dari 1000 meter di atas permukaan air laut. $^{2}$

World Health Organization (WHO) mencatat negara Indonesia sebagai negara dengan kasus Demam Berdarah tertinggi di Asia Tenggara. Dari jumlah keseluruhan kasus tersebut, sekitar 95\% terjadi pada anak di bawah 15 tahun. ${ }^{3}$

Hingga saat ini pengendalian nyamuk belum bisa di tanggulangi dengan optimal. Disamping penyebarannya yang sangat luas dari wilayah perkotaan hingga ke pelosok pedesaan, nyamuk tersebut juga sangat mudah berkembang biak terutama dilingkungan sekitar tempat manusia beraktivitas. Tempat perindukan nyamuk tersebut sangat bervariasi, tetapi umumnya lebih menyukai berbagai macam tempat penampungan air jernih yang banyak terdapat disekitar pemukiman penduduk, seperti bak mandi, tempayan dan barang-barang bekas yang menampung sisa-sisa hujan. ${ }^{4}$

Aktivitas dan metabolisme nyamuk Aedes spp dipengaruhi secara langsung oleh faktor lingkungan yaitu: temperatur, kelembaban udara, tempat perindukan, dan curah hujan. Nyamuk Aedes membutuhkan rata-rata curah hujan lebih dari $500 \mathrm{~mm}$ per tahun dengan temperatur ruang $32-34^{\circ} \mathrm{C}$ dan temperatur air $25-30^{\circ} \mathrm{C}$, $\mathrm{pH}$ air sekitar 7 dan kelembaban udara sekitar 70\%. Keberhasilan perkembangan nyamuk Aedes spp ditentukan oleh tempat perindukan yang dibatasi oleh temperatur tiap tahunnya dan perubahan musim. $^{5}$

Dalam siklus hidupnya, nyamuk Aedes sppmengalami empat stadium yaitu telur, larva, pupa,dan dewasa. Faktor lingkungan biotik dan abiotik berpengaruh terhadap kehidupan nyamuk Aedes, faktor abiotik seperti curah hujan, temperatur dan evaporasi. Dan faktor biotik seperti predator, kompetitor dan makanan di tempat perindukan. ${ }^{5,6}$

Larva Aedes dapat tumbuh hingga dewasa pada media perindukan dari campuran kotoran ayam, kaporit dan air sabun dengan konsentrasi setara polutan air di alam. Diduga, ada perubahan fisiologis dan perilaku bertelur dalam beradaptasi dengan kondisi lingkungan. Penelitian dari Sayono tahun 2011 membuktikan bahwa larva Aedes spp mampu bertahan hidup dan bertumbuh pada berbagai jenis air di alam sebagai tempat perindukan. ${ }^{5}$

Berdasarkan beberapa faktor diatas yang berpengaruh terhadap pertumbuhan larva nyamuk Aedes spp sebagaimana dikemukakan sebelumnya maka diduga bahwa faktor temperatur, kelembaban, $\mathrm{pH}$ air, curah hujan dan tempat penampungan air dapat menjadi salah satu atau beberapa faktor kunci yang menentukan kepadatan stadium larva nyamuk Aedes spp., Penelitian ini bertujuan untuk mengetahui faktor lingkungan dalam hal ini lebih dikhususkan pada jenis air perindukan yang memiliki hubungan dengan ketahanan hidup dan pertumbuhan larva Aedes spp.

\section{METODE PENELITIAN}

Penelitian ini bersifat eksperimental laboratorium dengfan metode deskriptif, dalam hal ini pengambilan sampel dilakukan di Kecamatan Malalayang, Kota Manado. Penelitian dilakukan di Laboratorium Parasitologi Fakultas Kedokteran Universitas Sam Ratulangi Manado. Penelitian dan pengumpulan sampel dilakukan dari November 2013 - Januari 2014. Sampel penilitian diambil dengan cara mengumpulkan telur larva Aedes spp dengan menggunakan perangkap ovitrap. Pengambilan sampel menggunakan metode Simple Random Sampling, dimana sampel diambil secara acak. Telur kemudian dipelihara di Laboratorium sampai menjadi nyamuk berumur 4 hari, jumlah larva yang diperlukan untuk penelitian sebanyak 100 ekor. 
Jacob, Pijoh, Wahongan; Ketahanan Hidup dan Pertumbuhan Nyamuk...

Besar sampel diukur dengan rumus:

$$
\begin{aligned}
& n=\left(\frac{Z a S}{d}\right)^{2} \\
& n=\left(\frac{1,96 \times 5}{1}\right)^{2}=96
\end{aligned}
$$

Variabel bebas penelitian yaitu jenis air media perindukan sedangkan variabel terikat adalah jumlah nyamuk Aedes yang hidup dan mati, jumlah nyamuk yang menjadi pupa dan yang menjadi imago. Data akan diolah secara manual dalam bentuk persentase dan grafik.

\section{HASIL}

Dalam penelitian ini telah dilakukan pengumpulan data tentang ketahanan dan pertumbuhan nyamuk Aedes spp pada berbagai jenis air perindukan, dengan jumlah sampel nyamuk sebanyak 100 ekor selama 15 hari.

\section{Perindukan air comberan (got)}

Gambar 1 dan Gambar 2 menunjukan nyamuk Aedes spp mampu hidup lebih dari 15 hari dengan persentase kehidupan 100\% dan persentase kematian $0 \%$. Secara keseluruhan proses pertumbuhan nyamuk Aedes terjadi hampir pada semua nyamuk yang diujikan, nyamuk Aedes mulai bertumbuh menjadi pupa pada hari ke-9 sebanyak 36\% dan kemudian naik menjadi 96\% pada hari berikutnya, pupa yang ada mulai berkembang menjadi imago (nyamuk muda) pada hari ke-11 (17\%), hari ke-12 (59\%) dan hari ke-13 (69\%).

\section{Perindukan air limbah sabun}

Gambar 1 dan Gambar 2 menunjukan bahwa nyamuk Aedes spp tidak dapat bertahan dan tumbuh pada perindukan air limbah sabun. Dari penelitian yang dilakukan diketahui bahwa nyamuk Aedes hanya mampu bertahan pada hari ke-1. Hari ke-2 nyamuk Aedes langsung mengalami kematian $100 \%$ sampai hari ke-15. Proses pertumbuhan nyamuk tidak terjadi pada penelitian ini dikarenakan nyamuk yang hanya mampu bertahan selam satu hari saja.

\section{Perindukan air sumur gali}

Pada Gambar 1 dan Gambar 2 menunjukan nyamuk Aedes hanya mampu hidup sampai hari ke-15 dengan presentase nyamuk yang hidup mengalami penurunan dari hari ke hari. Nyamuk yang hidup pada hari ke-1 sebanyak 100\% kemudian turun mencapai $72 \%$ pada hari ke-7 dan pada hari ke-10 turun menjadi 8\%. Pada penelitian ini nyamuk Aedes membutuhkan waktu 10 hari untuk berkembang menjadi pupa $8 \%$, hari ke-13 (12\%), hari ke-14 (16\%), pupa yang ada tidak berkembang menjadi imago dan mati pada hari ke-15.

\section{Perindukan air PAM}

Gambar 1 dan Gambar 2 menunjukan ketahanan nyamuk Aedes spp hampir sama dengan nyamuk pada sumur gali, nyamuk yang ada hanya mampu bertahan sampai hari ke-28. Ketahanan hidup nyamuk pada hari ke-1 (100\%), hari ke-7 turun menjadi $72 \%$, dan hari ke-17 menjadi 4\%. Pertumbuhan nyamuk menjadi pupa muncul pada hari ke-12 sebanyak (8\%), dan menurun pada hari ke-18 (4\%). 


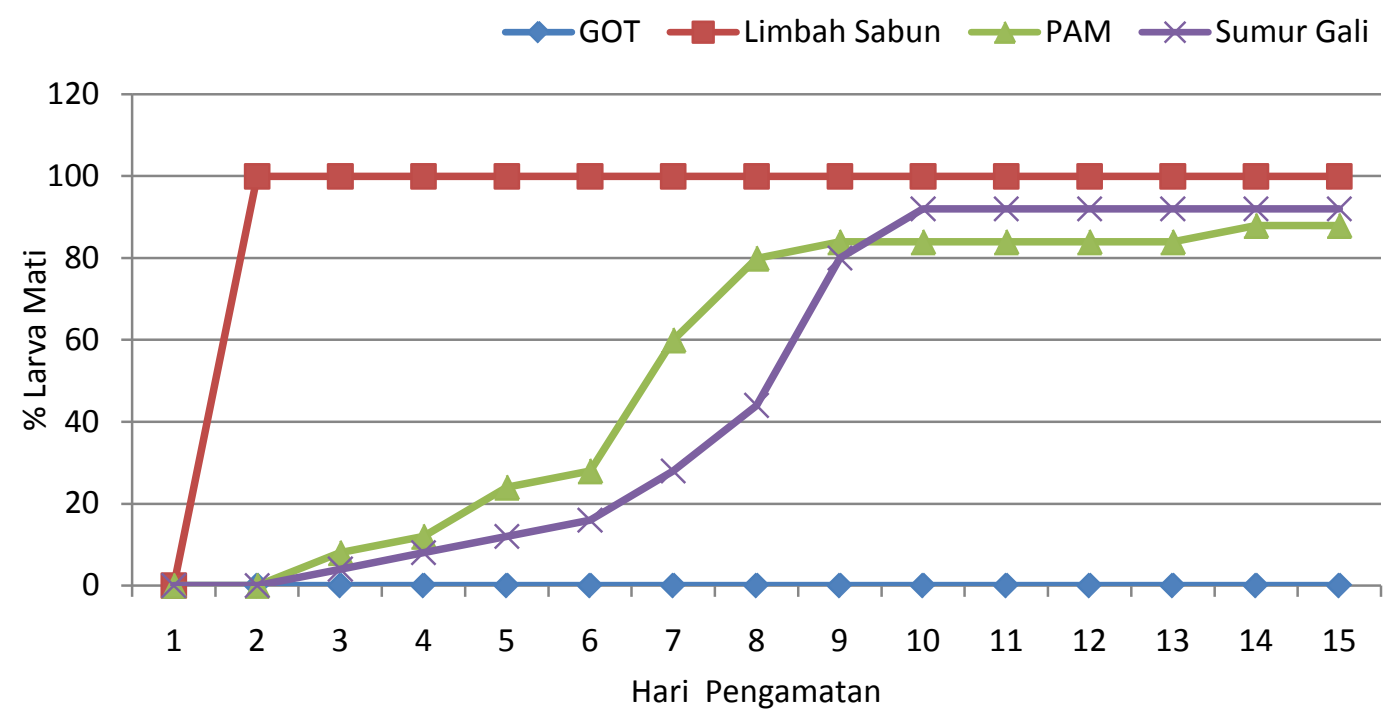

Gambar 1. Ketahanan dan pertumbuhan larva Aedes spp pada berbagai jenis air perindukan.

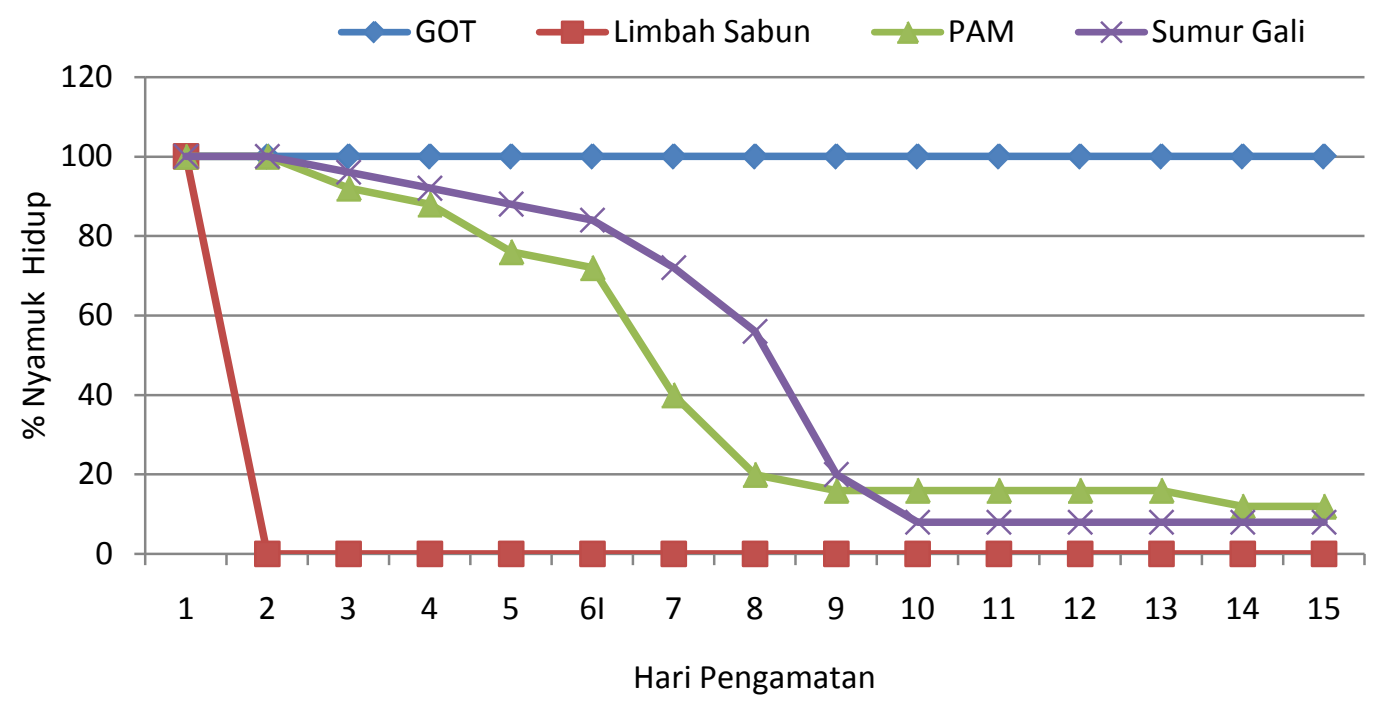

Gambar 2. Ketahanan hidup nyamuk Aedes spp pada berbagai jenis air perindukan.

\section{BAHASAN}

Dari hasil penelitian diketahui bahwa air limbah sabun tidak memungkinkan nyamuk Aedes untuk dapat hidup dan bertumbuh dibandingakan dengan jenis perindukan air comberan, sumur gali dan PAM. Hal ini disebabkan karena dari faktor yang mempengaruhi ketahanan dan pertumbuhan nyamuk Aedes spp didapati, $\mathrm{pH}$ yang terkandung pada air limbah sabun bersifat basa, yaitu 12,8. Derajat keasaman (pH) air perindukan merupakan faktor yang sangat menentukan kelangsungan hidup dan pertumbuhan nyamuk Aedes spp. Nyamuk Aedes tidak akan mampu bertahan atau mati pada saat $\mathrm{pH} 3$ dan $\geq 12$. Aedes tidak mampu berkembang menjadi nyamuk dewasa. Selain $\mathrm{pH}$, kelangsungan hidup dan pertumbuhan nyamuk juga bergantung pada keberadaan plankton sebagai makanan. Jenis plankton pada air SGL dan PAM lebih sedikit (3 dan 2 jenis) dibandingkan dengan air campuran seperti pada air got. Perindukan air PAM memiliki hasil yang hampir sama dengan perindukan air sumur gali. Keadaan ini disebabkan karena meskipun $\mathrm{pH}$ air PAM termasuk netral, 
Jacob, Pijoh, Wahongan; Ketahanan Hidup dan Pertumbuhan Nyamuk...

namun kematian nyamuk juga tinggi karena terdapat kandungan kaporit $\left(\mathrm{Ca}\left(\mathrm{OCl}_{2}\right)\right)$ yang bersifat desinfektan.

\section{SIMPULAN DAN SARAN}

Nyamuk Aedes spp tidak hanya mampu hidup pada perindukan air jernih saja, tapi dapat juga bertahan hidup dan tumbuh normal pada air got yang didiamkan dan menjadi jernih. Pada air sumur gali dan PAM ketahanan hidup nyamuk Aedes spp sangat rendah dan tidak dapat tumbuh normal, sedangkan air limbah sabun mandi tidak memungkinkan untuk hidup nyamuk Aedes spp. Sehingga masyarakat perlu lebih waspada terhadap genangan air got yang jernih karena dapat menjadi habitat perindukan nyamuk Aedes spp. Kewaspadaan juga diberikan bagi pengelolah program pengendalian vektor dan masyarakat dalam hal pemberantasan sarang nyamuk, tidak hanya pada air yang jernih saja.

\section{DAFTAR PUSTAKA}

1. Wahyuningsih EN, Rahardjo M, Hidayat $\mathrm{T}$. Keefektifan penggunaan dua jenis ovitrap untuk pengambilan contoh telur Aedes spp. di lapangan. Jurnal Entomologi Indonesia Universitas Diponegoro. September 2009;6(2).
2. Hadi Kesumawati Upik. Penyakit tular vektor: demam berdarah dengue. Bagian Parasitologi \& Entomologi Kesehatan IPB, Oktober 2010.

3. Adifian, Ishak H, Ane LR. Kemampuan adaptasi nyamuk Aedes aegypti dan Aedes albopticus dalam berkembang biak berdasarkan jenis air. Fakultas Kesehatan Masyarakat Universitas Hassanudin, Maret 2013.

4. Gionar RY, Rusmiarto Sapotro, Susapto Dwiko, Elyazar FR Iqbal, Bangs JM. Sumur sebagai habitat yang penting untuk perkembangbiakan nyamuk Aedes aegypti. Buletin Penelitian Kesehatan. Januari 2001.

5. Hariyono P. Uji bakteriologis air sumur di Kecamatan Semampir Surabaya [Skripsi]. Surabaya: Fakultas Sains Dan Teknologi Universitas Airlangga; 2011.

6. Sayono, Qoniatum S, Mibhfakhudin. Pertumbuhan larva Aedes aegypti pada air tercemar. Fakultas Kesehatan Masyarakat Universitas Muhammadiyah Semarang. 2011; 7(1).

7. Ananda S. Pengaruh Suhu, kaporit, dan $\mathrm{pH}$ terhadap pertumbuhan cendawan entomopatogen transgenik Aspergullus Niger-GFP dan patogenitasnya pada larva nyamuk Aedes aegypti. 2009. Departemen Biologi. Fakultas MIPA. Institut Pertanian Bogor.http://repository.ipb.ac.id/bitstream/h andle/123456789/44330/Abstract \%20G09san.pdf?sequence=3 